\title{
Water-Pumping Using Powered Solar System - More than an Environmentally Alternative: The Case of Toshka, Egypt
}

\author{
Ahmed G. Abo-Khalil ${ }^{1}$, Sameh S. Ahmed ${ }^{2}$ \\ ${ }^{1}$ Electrical Engineering Department, Assiut University, Assiut, Egypt \\ ${ }^{2}$ Mining and Metallurgical Engineering Department, Assiut University, Assiut, Egypt \\ Email address: \\ a.abokhalil@mu.edu.sa (A. G. Abo-Khalil)
}

\section{To cite this article:}

Ahmed G. Abo-Khalil, Sameh S. Ahmed. Water-Pumping Using Powered Solar System - More than an Environmentally Alternative: The Case of Toshka, Egypt. Journal of Energy and Natural Resources. Special Issue: Electrical Power Resources: Coal versus Renewable Energy. Vol. 5, No. 1-1, 2016, pp. 19-25. doi: 10.11648/j.jenr.s.2016050101.14

\begin{abstract}
In this paper, a solar powered water pumping system for supplying water to irrigate part of Toshka project is proposed. The design considers several factors including the crop, the size of the planting region, the number of peak sun hours, the efficiency of the solar array and its electronics, the pumping elevation and the pump efficiency. The pumping power to irrigate different crops that could be grown in Toshka is calculated. The proposed system consists of a vector control of induction motor coupled with a centrifugal hydraulic pump, the induction motor drive is fed by DC-DC converters with maximum power point tracking (MPPT) to extract the whole energy that the PV panels can generate. The effectiveness of the proposed system has been verified by simulation results and showed reasonable level for implementation that would assist the development at the region both economically and environmentally.
\end{abstract}

Keywords: Photovoltaic, Maximum Power Point, Toshka Project, Water Pumping

\section{Introduction}

Over the past 30 years, the population of Egypt has risen from 20 to nearly 90 million and it has been predicted that this trend will continue, reaching an anticipated 120 million in the next 10. The Nile valley in Egypt covers an area of about $11,000 \mathrm{~km}^{2}$ with an average width of $12 \mathrm{~km}^{2}$. The net irrigated area in the valley is $8600 \mathrm{~km}^{2}$ [1]. Stretching the length of Egypt from north to south and occupying a valley around the Nile River, it covers 3 percent of Egypt's land but is home to 96 percent of its people. The majority of Egyptians live around the Nile. An estimated $60 \%$ live in urban areas - in cities which are growing faster than infrastructure to support them while the mounting numbers in rural areas provide a ready supply of new migrants to the towns.

The Toshka New Valley project is meant to develop agricultural production and create new jobs away from the Nile Valley by creating a second Nile Valley. This includes redirecting water from Lake Nasser to irrigate part of the Western Desert of Egypt via canals. The project is meant to help Egypt deals with its growing urban population and was touted as the "New era of hope for Egypt". The Toshka Project is intended to house more than three million residents and to increase Egypt's arable land area by $10 \%$. The project is also designed to create a new delta south of the Western Desert parallel to the Nile, adding 520,231 acres to Egypt's cultivated area.

To irrigate the major part of this land, $\$ 1$ billion was spent on creating the world's largest pumping station to extract five billion cubic meters of water from Lake Nasser annually, and digging the Sheikh Zayed Canal. The main canal (completed in 2002 ) is $50 \mathrm{~km}$ long, $30 \mathrm{~m}$ wide and $6 \mathrm{~m}$ deep, with four branch canals totaling $159 \mathrm{~km}$ in length, and a network of roads linking Toshka to another irrigation project at East Oweinat in the Western Desert [2].

A small area of Toshka New Valley relies on the underground water according to the developing plans of the Ministry of Irrigation and Water Resources. It is known that the presence of the Nubian Sandstone reservoir which economic studies have shown that rates of groundwater development in the South Valley region and the Western Sahara can be up to approximately 2.5 billion cubic meters annually, equivalent to almost 3,000 times the annual flow of the Nile,. It is shared with Sudan, Chad and Libya [3].

Nevertheless, most of the surface water from the Nile is nearly fully utilized; most of groundwater resource is almost undeveloped. In Toshka, beside the main canals driven from 
Lake Nasser, there is a possibility of utilizing the groundwater at a western part of the project.

The number of targeted wells is 316 productive wells to grow about 36 thousand acres in scattered areas. The data collected shows that the depth to the water aquifer ranges from 80 to $100 \mathrm{~m}$ [4].

The Egyptian government plans to distribute these 36 thousand acres of Toshka lands to young people up to 100 acres. There is no significant irrigation infrastructure in place to support the irrigation needs of the proposed crop. Installation of irrigation systems that stores and delivers water to the crops is now necessary. As there is also no electrical grid infrastructure in these lands, installation of irrigation systems is a must.

\section{Technical Aspects}

Far from the electric grid, it is common to use fossil fuels to power generators in water pumping operations. While these systems can provide power where needed, there are some significant drawbacks, including [5]:

1) Fuel has to be transported to the generator's location, which may be quite a distance over some challenging roads and landscape.

2) Their noise and fumes can disturb communities.

3) Fuel costs add up, and spills can contaminate the land.

4) Generators require a significant amount of maintenance and, like all mechanical systems; they break down and some parts need to be replaced that are not always available.

Not to mention, points 1 and 2 have environmental impacts that need further efforts to overcome.

For many water pumping needs, the alternatives are: solar energy (photovoltaic system), wind power system, or nuclear station. This research is considering solar energy as an alternative. One more significant advantage for photovoltaic water pumps, they do not require the presence of an electric line in order to operate. This makes them extremely useful in rural locations such as ranches and farms, or in the developing world where electricity is often not available or it is far cheaper to purchase a solar panel than it is to run power lines. Therefore, the authors believe that solar water pump is a perfect solution to be used in the water pumping of Toshka project where power lines are not available and transport of fuel is expensive. Moreover its less environmental impacts.

Water pumping has regularly been a technical challenge, solving the problems of drinking water supply and regular irrigation was a prerequisite for the development of civilization in many of the ancient empires. The PV pumping systems are being installed worldwide, and there were approximately 60,000 unit such systems in 1998 which increased rapidly during the last few years. The ongoing efforts on performance improvement and modeling, system sizing and optimization, and performance of PV systems on the basis of experimental measurements have resulted in commercially acceptable, economically affordable, and easily maintainable with least possible expertise. These developments have lead and are contributing to the improvement of the lives of remotely located dwellings [6].

Particularly in areas of average daily solar radiation intensity exceeding $5 \mathrm{kWh} / \mathrm{m}^{3} /$ day and of water requirements less than $100 \mathrm{~m}^{3} /$ day, PV systems had proven reliability and economic feasibility in comparison with diesel powered pumping systems. In addition, these systems need very limited maintenance, since they operate without storage batteries and they do not pollute the environment [7].

In this paper, an overall design and simulation of PV-powered pumping is developed. This work then investigates the feasibility of using solar power for the pumping power requirement for drip irrigation systems. The effectiveness of the proposed system has been verified by simulation results.

\section{Toshka Project Characteristics and Energy Requirement}

The Toshka project is located in a portion of Egypt's Western Desert known as the Toshka Depression. Situated to the west of Lake Nasser between the Upper (southern) Egyptian cities of Aswan and Abu Simbel as shown in Fig. 1. There are about $3200 \mathrm{~km}^{2}$ of land lower in elevation than Lake Nasser and lower even than the River Nile prior to the creation of Lake Nasser. Before discussing the Toshka Project, it is important to first identify the geography of the project (see Fig. 2) [4]:

- Toshka Region;

- Toshka Depression;

- Toshka Bay;

- Toshka Spillway;

- Toshka Canal;

- Mubarek Pump Station (MPS) which is the largest pump station in the world.

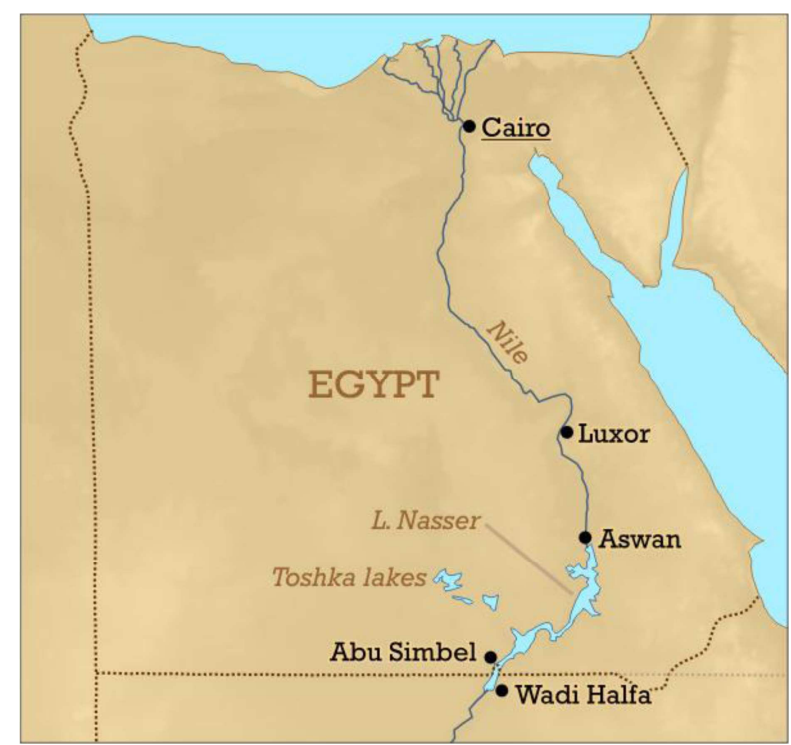

Fig. 1. Location of Toshka region. 


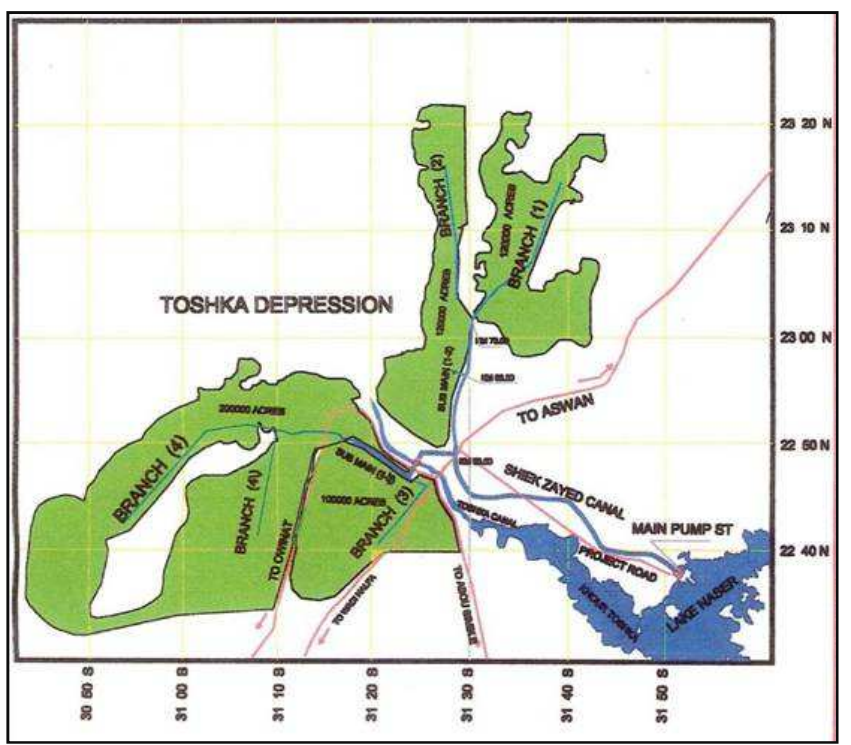

Fig. 2. Outline of Toshka Project.

Toshka Region is located southwest of Aswan, about 1000 $\mathrm{km}$ south of Cairo. Toshka Depression is a natural depression in that area with an average diameter of $22 \mathrm{~km}$ and a storage capacity of 120 billion $\mathrm{m}^{3}$. Toshka Bay is a shoot off Lake Nasser towards Toshka. Toshka Spillway is a free spillway discharging the water of Lake Nasser when it exceeds its highest storage level of $187 \mathrm{~m}$. It is a $22-\mathrm{km}$ long, manmade canal connecting Toshka Bay with the Toshka Depression and works as a safety valve for Lake Nasser, upstream of the High Dam.

Toshka Canal is the heart and soul of the Toshka Project. It is a new canal conveying the excess water of Lake Nasser that is pumped into it through a giant pumping station that elevates the water to flow through the canal to reclaim and irrigate 520,231 acres.

The Toshka project begins with the main pumping station, also known as Mubarak pumping station (MPS), and is considered as the largest pump station in the world. The characteristics of MPS operation are as follow:

1- The required annual water for the total area of the project is $5.5^{*} 10^{9} \mathrm{~m}^{3}$ per year and the designed discharge capacity of a single pump is estimated to be about $\left(17^{*} 10^{6}\right.$ $\mathrm{m}^{3} /$ day).

2- Minimum and maximum suction levels (minimum and maximum operational water levels in Lake Nasser) are $147 \mathrm{~m}$ and $182 \mathrm{~m}$, respectively.

3- Delivery level (Toshka Canal) is $201 \mathrm{~m}$, consequently, minimum and maximum statically water raising heads are 19 $\mathrm{m}$ and $54 \mathrm{~m}$ respectively.

Many studies were performed to determine the required power and the energy for the project. Operation scenarios are different in each study; one scenario determines the peak power requirements for pumping stations by about $165 \mathrm{MW}$, of which $105 \mathrm{MW}$ is allocated for main Mubarak Pumping Station. The associated annual energy requirements are about $950 \mathrm{GWh}$, of which $575 \mathrm{GWh}$ is allocated for the main pumping station [8].

\section{Photovoltaic Pumping System}

Photovoltaic pumping system is a standard pump equipped with an electric motor, provided in electrical energy by photovoltaic panels installed on the. This pump is intended to pump water from the basement to make it accessible to users as shown in Fig. 3 [9]. Before selecting the system components, the system should be roughly sized to allow viewing of approximate component sizes. The sizing involved determining the area for implementing the solar powered irrigation system and the water needed for domestic use. It is also included calculation of the required pumping power the solar panel array area.

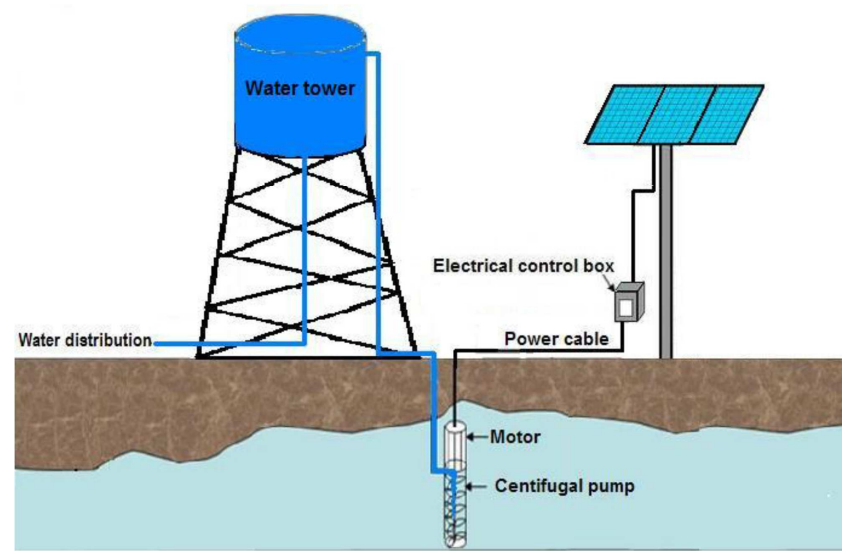

Fig. 3. Photovoltaic water pumping without batteries with a tank to store water [8].

\subsection{Determining the Area to be Irrigated Using the PV System}

The Egyptian government plans to distribute up to 100 acres for the Egyptian individual farmers.

Total land area $(10$ acres $)=40469 \mathrm{~m}^{2}$

Therefore, total crop area (taking into account area subtracted for PV arrays, roads, drainage and water tank) is $32000 \mathrm{~m}^{2}$.

\subsection{Crop Water Requirements}

Toshka climate is characterized by warmth and drought which helps to speed the maturity of fruits and vegetables in the early times from their counterparts in neighboring countries. Different types of crops are grown in Toshka, such as: wheat, maize, citrus, peanuts, watermelon. These crops water requirements are shown in table 1 [10]. If we take of wheat as an example, to calculate the amount of water needed during the planting period, irrigation needs for period for wheat could be calculated as $32000 \mathrm{~m}^{2} \times 0.6 \mathrm{~m}=19200 \mathrm{~m}^{3}$. Therefore, Total Crop Water required (or Water deficit) for that period could be determined by Irrigation needs for period $+10 \%$ evaporation loss $+10 \%$ leakage loss $=23040 \mathrm{~m}^{3}$. Hence, total crop water requirements per day would be $23040 \mathrm{~m}^{3} / 150=153.6 \mathrm{~m}^{3}$. 
Table 1. Indicative Values of the Total Growing Period [10].

\begin{tabular}{lll}
\hline Crop & $\begin{array}{l}\text { Total growing period } \\
\text { (days) }\end{array}$ & $\begin{array}{l}\text { Crop water need }(\mathrm{mm} / \text { total } \\
\text { growing period) }\end{array}$ \\
\hline Wheat & $120-150$ & $450-650$ \\
Bean Dry & $95-110$ & $300-450$ \\
Maize & $125-180$ & $500-800$ \\
Tomato & $135-180$ & $400-800$ \\
Potato & $105-145$ & $500-700$ \\
Onion dry & $150-210$ & $350-550$ \\
Melon & $120-160$ & $400-700$ \\
Citrus & $240-365$ & $900-1200$ \\
\hline
\end{tabular}

\subsection{Calculating the Required Pumping Power}

Photovoltaic water pump sizing is the determination of the power of the solar generator that will provide the desired amount of water. The photovoltaic water pump sizing consists of [8]:

- Assessment of daily water needs of the population to know the rate flow required;

- calculation of hydropower helpful;

- determining of the available solar energy;

- determining of the inclination of the photovoltaic generator which can be placed;

- determination of the month sizing (the month in which the ratio between solar radiation

- and hydropower is minimum);

- sizing of the PV generator (determination of the required electrical energy);

The required PV size can be determined from:

$$
P_{p v}=\frac{g * \rho_{s} * Q_{s} * T_{H}}{3600 * G^{*} \eta_{p} *\left(1-\eta_{l}\right)}
$$

Where, $P_{p v}$ is the electrical power (W);

$g$ is acceleration of gravity $\left(9.81 \mathrm{~m} . \mathrm{s}^{-2}\right)$;

$\rho_{s}$ is water density $\left(1000 \mathrm{~kg} / \mathrm{m}^{3}\right)$;

$Q_{s}$ is daily water needs $\left(\mathrm{m}^{3} /\right.$ day);

$T_{H}$ is the total head (m);

$\eta_{p}$ is pump system efficiency;

$\eta_{l}$ is the system loss due to the temperature and dust.

Assuming a $6 \mathrm{~kW} / \mathrm{m}^{2}$ irradiation, $153.6 \mathrm{~m}^{3}$ daily water need, $100 \mathrm{~m}$ total head, $40 \%$ pump system efficiency, and $25 \%$ system loss. By using (1), the PV electrical power is $23 \mathrm{~kW}$.

\section{System Description}

Figure 4 shows a block-diagram of a stand-alone photovoltaic generator, boost converter for maximum power point tracking, DC/AC inverter, and induction motor coupled with a pump load. A MPPT is designed and implemented to extract the maximum power from a PV source using a boost converter. The MPP varies as a result of changes in its electrical characteristics which in turn are functions of irradiation level, temperature, ageing and other effects. The MPPT maximizes the power output from panels for a given set of conditions by detecting the best working point of the power characteristic and then controls the current through the panels or the voltage across them. The voltage and current, which is detected in real time, are used to extract the MPPT. The output of the boost converter is fed to the current controlled voltage source inverter (CC-VSI). The (CC- VSI) acts as a source of excitation with controlled frequency and it is responsible to feed power to the cage induction motor' drive. For effective utilization of the solar energy, optimum efficiency operation of the drive is desired throughout the operating range of the motor. This is achieved by maintaining a proper balance between the flux $\left(i_{d s}\right)$ and torque $\left(i_{q s}\right)$ components of the motor current, which in turn equalizes the fixed and the variable losses of the cage motor. For this purpose, the torque and flux component of the motor current are also logically related with the power at the output of PV array. Therefore, the available solar power is optimally converted into the useful mechanical power.

The induction motor d-axis current component is generally set to maintain the rated field flux in the whole range of speed, while the q-axis current component to control the motor torque based on the PV output power. The motor speed is estimated based on the motor voltages and currents. The detailed block diagram is shown in Fig. 5 [11].

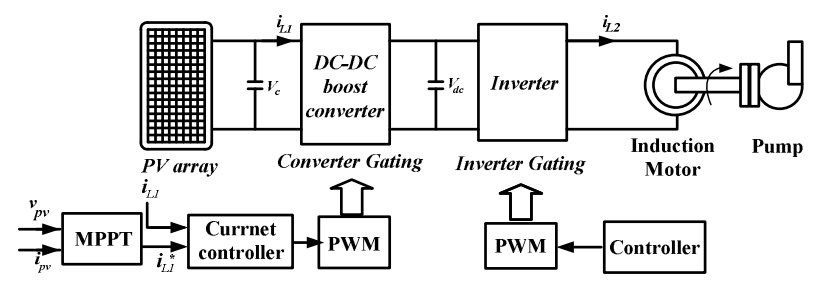

Fig. 4. Control circuit for the PV system.

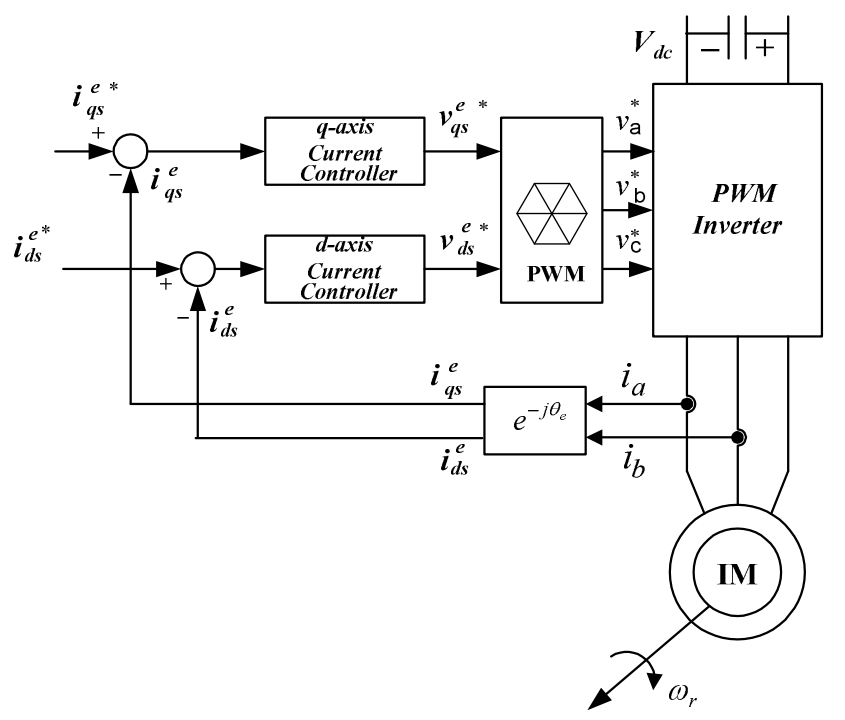

Fig. 5. The block diagram of the controlled induction motor. 


\section{Modeling of PV Module}

Solar cells are devices that convert photons into electrical potential in a PN junction, of which equivalent circuit is shown in Fig. 6(a). PV module is composed of $n$ of these cells in series, as shown in Fig 6(b), in order to reach a high voltage at the terminals. Due to the complex physical phenomena inside the solar cell, manufacturers usually present a family of operating curves (V-I) as shown in Fig. 7(a). These characteristics are obtained by measuring the array volt-ampere for a different illumination values. From these characteristics, the optimum voltage or current, corresponding to the maximum power point, can be determined. It is clearly seen in Fig. 7(b) that the current increases as the irradiance levels increase. The maximum power point increases with a steep positive slope proportional to the illumination.

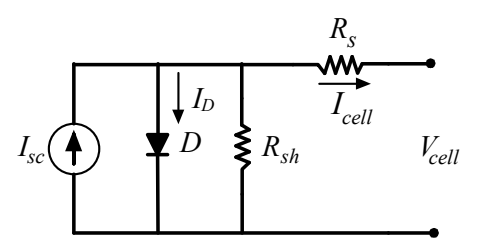

(a)

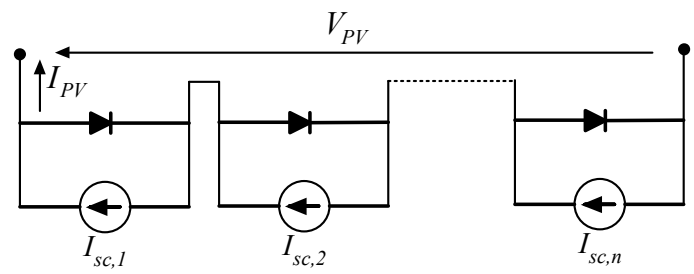

(b)

Fig. 6. Equivalent circuit of PV array.

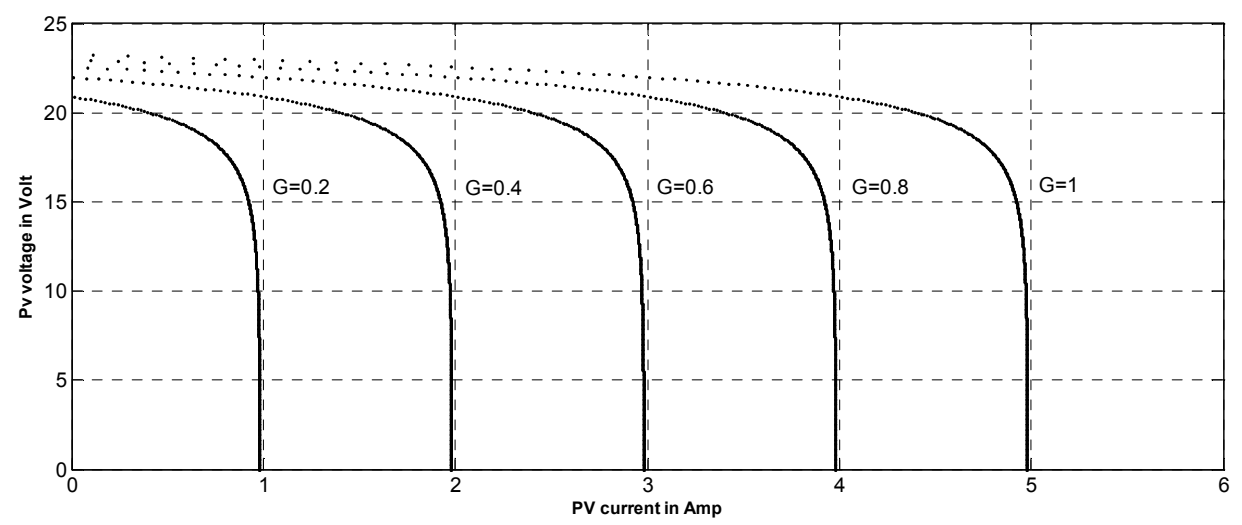

(a)

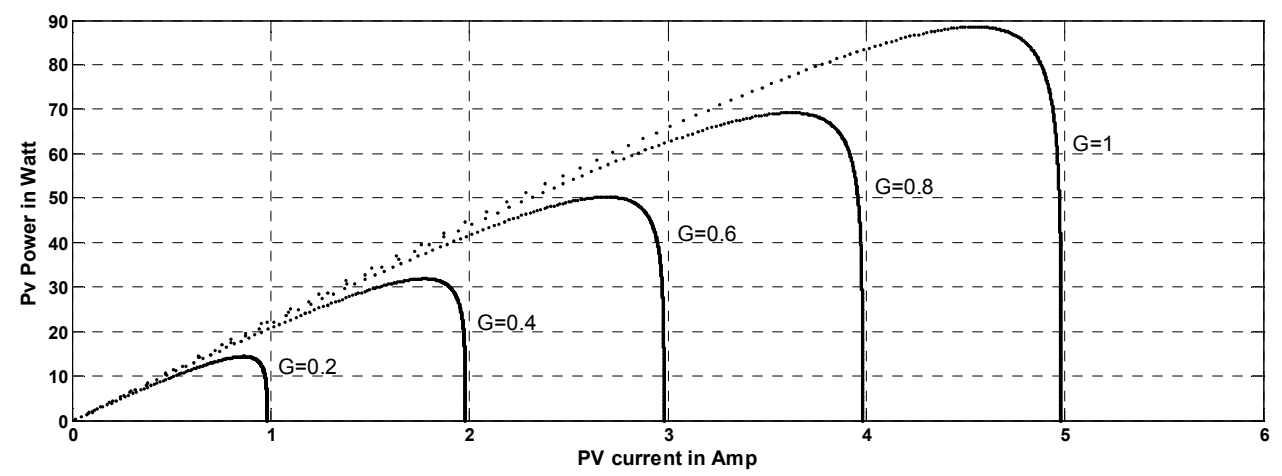

(b)

Fig. 7. (a) V-I characteristics, and (b) P-I characteristics at constant temperature $\left(25{ }^{\circ} \mathrm{C}\right)$.

The main parameters which influence the illumination levels on a surface at a fixed tilt on earth are the daily and seasonal solar path, the presence of clouds, mist, smog and dust between the surface and the sunlight, and the shade of the object positioned such that the illumination level is reduced, etc.

The equation of the PV output current $I$ is expressed as a function of the array voltage $V$

$$
I=I_{\mathrm{sc}}-I_{\mathrm{o}}\left\{e^{\frac{q\left(V+I R_{s}\right)}{K T_{k}}}-1\right\}-\left(V+I R_{\mathrm{s}}\right) / R_{\mathrm{sh}}
$$

where $V$ and $I$ represent the PV output voltage and current, respectively; $R_{s}$ and $R_{s h}$ are the series and shunt resistance of the cell (in Fig. 1); $q$ is the electronic charge; Isc is the light-generated current; Io is the reverse Saturation current; $K$ is the Boltzman constant, and $\mathrm{Tk}$ is the temperature in $K$.

Equation (2) can be written in another form as [11], [12]

$$
I=I_{s c}\left\{1-K_{1}\left[e^{K_{2} V^{m}}-1\right]\right\}-\left(V+I R_{\mathrm{s}}\right) / R_{\mathrm{sh}}
$$


where the coefficient $K_{1}, K_{2}$ and $\mathrm{m}$ are defined as

$$
\begin{aligned}
& K_{1}=0.01175, \\
& K_{2}=K_{4} /\left(V_{o c}\right)^{m}, \\
& K_{4}=\ln \left(\left(K_{1}+1\right) / K_{1}\right), \\
& K_{3}=\ln \left[\left(I_{s c}\left(1+K_{1}\right)-I_{m p p}\right) / K_{1} I_{s c}\right], \\
& m=\ln \left(K_{3} / K_{4}\right) / \ln \left(V_{m p p} / V_{o c}\right)
\end{aligned}
$$

and $I_{m p p}$ is the current at maximum output power, $V_{m p p}$ is the voltage at maximum power, $I_{s c}$ is the short circuit current and $V_{o c}$ is the open circuit voltage of the array.

Equation (3) is only applicable at one particular operating condition of illumination $G$ and cell temperature $T_{c}$. The parameter variations can be calculated by measuring the variation of the short-circuit current and the open-circuit voltage in these conditions using the parameters at the normal illumination and cell temperature. Equation (3) is used for the
I-V and P-V characteristics for various illumination and fixed temperature $\left(25\left[{ }^{\circ} \mathrm{C}\right]\right)$ in Fig. 7 .

\section{Simulation Results}

In order to demonstrate the effectiveness of the proposed MPPT, some simulations have been carried out. The proposed design is implemented in PSIM software for a photovoltaic water-pumping system as depicted in Fig. 8. Fig. 9 shows that the output power changes according to the illumination variation from $800\left[\mathrm{w} / \mathrm{m}^{2}\right]$ to $700\left[\mathrm{w} / \mathrm{m}^{2}\right]$ to $600\left[\mathrm{w} / \mathrm{m}^{2}\right]$. The new incremental duty ratio varies according to the change in DC/AC inverter reference current. These relations between the input and output are determined in the base-rule form. It is noticed that the fast dynamic performance at step variation of illumination level is obtained.

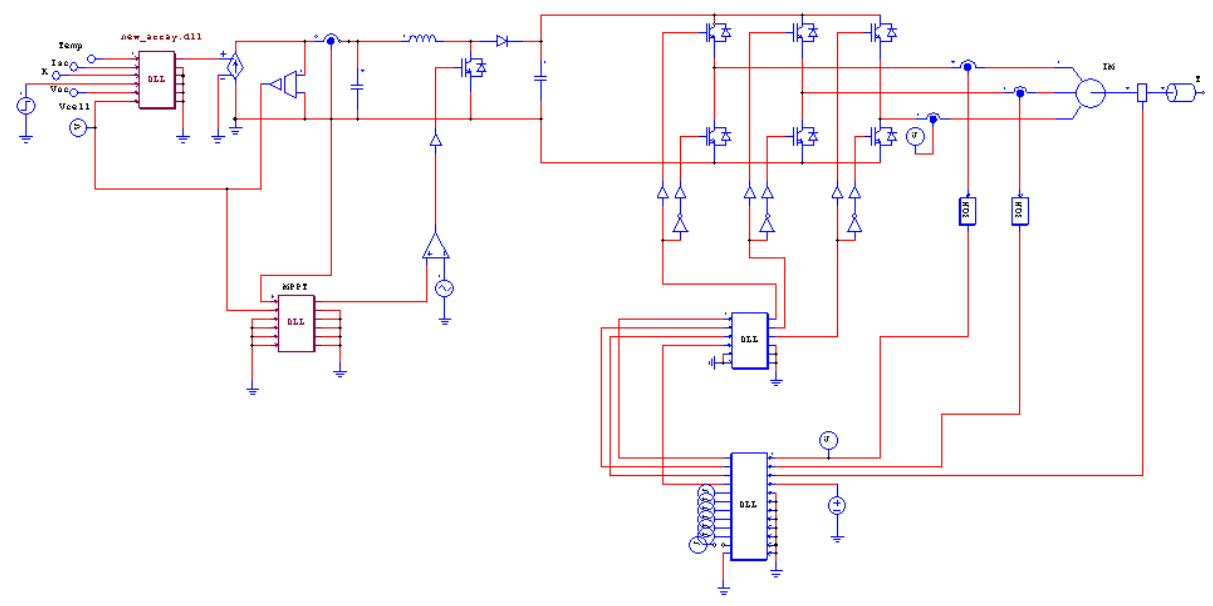

Fig. 8. Detailed model and control scheme of the grid-connected PV solar system in the PSIM environment.

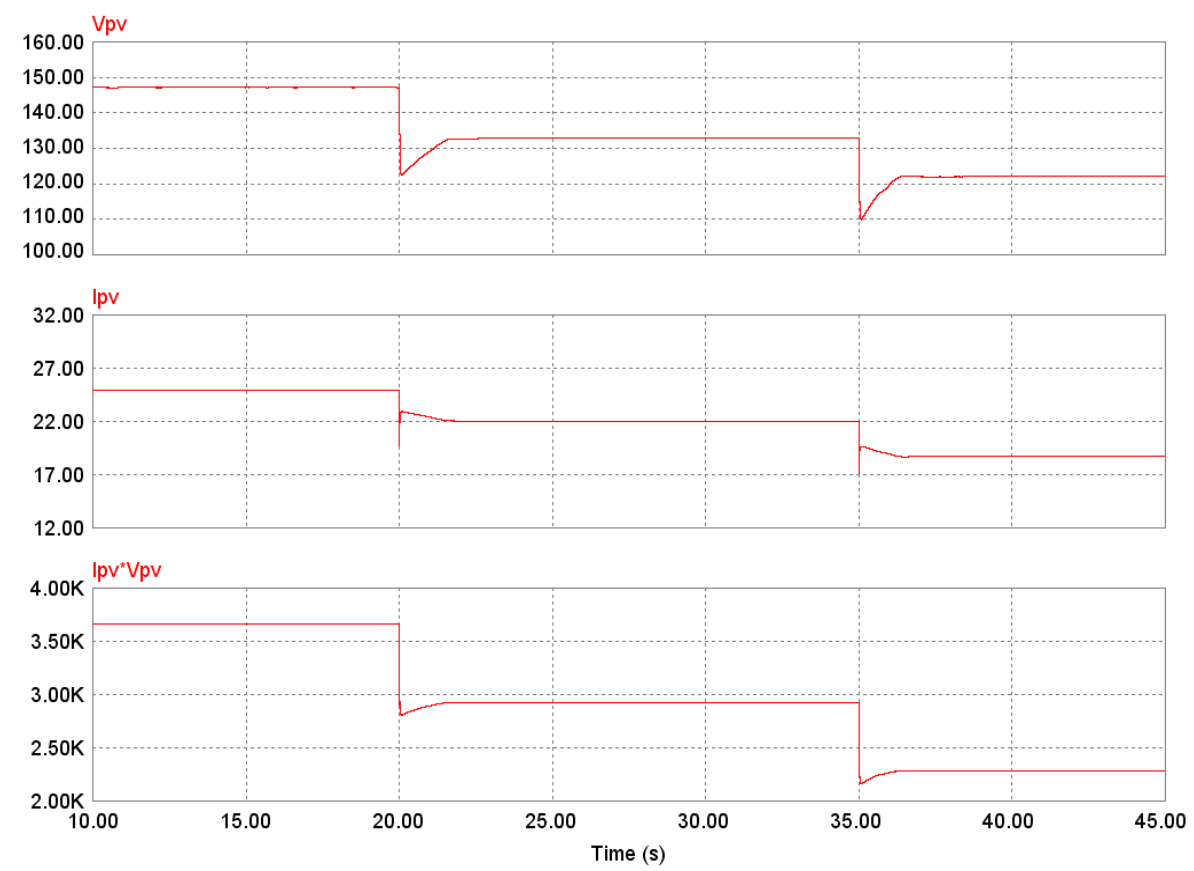

Fig. 9. PV voltage, current and power at different illumination levels. 


\section{Conclusions}

In this paper, a demonstration for the application of solar pumping system to provide the required power for irrigation was presented. Crop chosen, the size of the planting region, the number of peak sun hours, the efficiency of the solar and pump system were taken into consideration to calculate the required solar power. To verify the validity and robustness of the proposed system, the simulation results have been obtained with a squirrel-cage induction generator pumping system.

\section{References}

[1] Fatma A. R. Attia, et al., "A Hydrologic Budget Analysis for the Nile Valley in Egypt", Groundwater, Vol. 24, No. 4, pp 453-459, August 1986.

[2] A. F. Hassan, "The Toshka Project construction works, Toshka, Egypt," Toshka Research and Engineering Studies., 2001.

[3] K. Abu-Zeid, and A. Abdel Meguid, "Status of Integrated Water Resources Management Planning in Arab Mediterranean Countries", International Conference on Water Demand Management, World Bank Session, Dead Sea, Jordan, 2003.

[4] Ministry of Water Resources and Irrigation, Arab Republic of Egypt, "The Southern Valley Development Project (SVDP)," Cairo, Egypt, October, 2000.
[5] B. Eker, A. Akdogan, Protection methods of corrosion on solar systems, TMMOB Machinery Engineering Society, Mersin, Turkey, 2005.

[6] A. Z. Sahin and S. Rehman, "Economical Feasibility of Utilizing Photovoltaic for Water Pumping in Saudi Arabia," Hindawi Publishing Corporation, International Journal of Photo energy, Vol. 2012, Article ID 542416.

[7] N. M. Abdelsalam, M. M. Abdelaziz, A. F. Zobaa, and M. S. Aziz, "Toshka Project Electrical Power Demand (Mubarak Pump Station)" $12^{\text {th }}$ International Water Technology Conference, IWTC12,Egypt, pp. 503-517, 2008.

[8] M. Saïdou, K. Mohamadou, and S. Gregoire, "Photovoltaic Water Pumping System in Niger," Intec Open, pp. 183-193, 2013.

[9] C. Brouwer and M. Heibloem, "Irrigation Water Management," Food and Agriculture Organization (FAO) Training Manual No. 3.

[10] Byunggyu YU, Ahmed G. Abo-Khalil1, Mikihiko Matsui, Gwonjong Yu, "Sensorless Fuzzy Logic Controller for Maximum Power Point Tracking of Grid- Connected PV system" IEEE International Conference on Electrical Machines and Systems ICEMS, pp. 1-8, Nov. 2009.

[11] Ahmed G. Abo-Khalil, Y. S. Kim, and D. C. Lee, "Maximum Output Power Control of Wind Generation System Using Fuzzy Control," Korean Institute of Electrical Engineering Journal, vol. 54B, No. 10, Oct. 2005.

[12] Ahmed G. Abo-Khalil, "Gradient Approximation Based Maximum Power Point Tracking for PV Grid Connected System", IEEE Power Electronics and Drive Systems Conference PEDS, pp. 104-108, Dec. 2011. 